Family Involvement and R\&D Expenses in the Context of Weak Property Rights

Protection: An Examination of Non-state-owned Listed Companies in China

\author{
Alfredo De Massis, Ph.D. \\ Lancaster University Management School \\ Lancaster University, Lancaster, United Kingdom LA1 4YX \\ Tel: +44 1524594057 \\ Email: a.demassis@lancaster.ac.uk \\ Shujun Ding, Ph.D. \\ Telfer School of Management \\ University of Ottawa, Ottawa, Ontario, Canada \\ Tel: 1-613-562 5800 ext 4688 \\ Email: ding@telfer.uottawa.ca \\ Josip Kotlar, Ph.D. \\ Lancaster University Management School \\ Lancaster University, Lancaster, United Kingdom LA1 4YX \\ Tel: +44 1524594045 \\ Email: j.kotlar@lancaster.ac.uk \\ Zhenyu Wu, Ph.D. \\ I.H. Asper School of Business \\ University of Manitoba \\ 416 Drake Centre \\ Winnipeg MB Canada R3T 5V4 \\ Tel: (204)474-8425 \\ Email: zhenyu_wu@umanitoba.ca
}

Accepted for publication at the European Journal of Finance

http://www.tandfonline.com/doi/abs/10.1080/1351847X.2016.1200994

Please cite as: Alfredo De Massis, Shujun Ding, Josip Kotlar \& Zhenyu Wu (2016). Family involvement and R\&D expenses in the context of weak property rights protection: An examination of non-state-owned listed companies in China. The European Journal of Finance, DOI: 10.1080/1351847X.2016.1200994. 


\title{
Family Involvement and R\&D Expenses in the Context of Weak Property Rights Protection: An Examination of Non-state-owned Listed Companies in China
}

\begin{abstract}
The impact of family involvement on firm behaviour is an issue of global interest, yet paradoxically few studies examine the behaviour of family firms in the unique socio-political environment of China. We investigate the cross-institutional generalizability of the behavioural agency model, emphasizing the non-economic goals of controlling families as a driver of unique yet predictable behaviours in Chinese family firms and examine the relationship between family involvement and the $R \& D$ expenses reported by these firms. We propose that in a context of weak property rights protection such as China's, the opportunity for family owners to attain transgenerational control is subject to the additional risk of state predation. We consequently expect economic goals to prevail over family-centred noneconomic goals in Chinese family firms and hypothesize that their reported R\&D expenses increase with family involvement due to severe Type II agency problems. Moreover, we examine the effect of positive and negative performance feedback on this relationship. Longitudinal data from non-state-owned listed companies in China provide overall support for these contentions. We discuss the theoretical and practical implications of these findings.
\end{abstract}

Keywords: Family firms; R\&D expenses; family-centred goals; property rights; China JEL Classifications: G18, G38, M14 


\section{INTRODUCTION}

In contrast to the United States and most western developed economies, China has uncertain property rights (La Porta et al. 2004). Private firms are vulnerable to unauthorized interference by redistributors who may impose illicit charges, enforce regulations that may discriminate against private enterprises and restrict their access to critical factor resources allocated by state agencies. Furthermore, the Chinese government and its officials may take advantage of their authority to intervene in private firms, e.g., forcing the appointment of directors with political backgrounds, attaining control of the firm and appropriating rents in the long run (e.g., Wang and Qian 2011; Fan, Wong, and Zhang 2007). The lack of clearly defined and routinely enforced private property rights are a major risk in private ownership of Chinese firms and this is expected to produce different coping mechanisms.

The distinctiveness of family firms derives from the concentration of ownership and governance in a single-family unit (Tsang 2002) and from the vision of how the firm will benefit the family, potentially across generations (Chrisman et al. 2012; Chua, Chrisman, and Sharma 1999). Family firm theory emphasizes that these firms differ from non-family firms in that they are not only driven by economic performance but also by non-economic motives and family-centred goals (Chrisman et al. 2012; Chrisman and Patel 2012; Chua, Chrisman and De Massis 2015; Gómez-Mejía et al. 2007; Kotlar and De Massis 2013). These goals include the long-term fulfilment of family obligations, the preservation of the family dynasty and values, and the possibility to act altruistically with family members (Berrone, Cruz, and Gomez-Mejia 2012; Tagiuri and Davis 1992). These goals are all contingent on family control of the business beyond the incumbent generation (Pollak 1985; Zellweger et al. 2012). Pursuing family-centred goals requires certain property rights and the uncertainty of these rights in family firms in China requires finding alternative routes to pursue family-centred goals. Despite that China's distinctive institutional context is a significant challenge for 
family firms, very little research has examined the impact of family involvement on the strategic behaviour of Chinese family firms.

This study takes a first step towards closing this gap by examining the effect of uncertain property rights on Chinese family firm behaviour. Specifically, this study includes considerations on the distinct socio-political environment in which Chinese family firms operate to develop hypotheses on their R\&D behaviour, which is strongly linked to pursuing family-centred goals (Chrisman and Patel 2012; Kotlar et al. 2014a, b; Sciascia et al. 2015). The consideration of the unique socio-political environment in China leads us to expect that Chinese family firms put higher priority on financial wealth maximization, while considering alternative means to pursue the creation and preservation of socioemotional wealth (SEW). This shift in their decision-making framework and the stronger incentives to exploit private benefits at the expense of minority shareholders enable us to develop a set of hypotheses linking family involvement to the R\&D investment behaviour of Chinese firms and examine the moderating effects of positive and negative performance gaps on this relationship. We test our hypotheses on a longitudinal sample of non-state-owned listed firms in China from 2006 to 2010.

Generally consistent with our expectations, the findings indicate that family involvement is positively related to reported $R \& D$ investments in China. This result is in sharp contrast to contexts such as the United States and other countries where property rights are secure (Chrisman and Patel 2012; Munari, Oriani, and Sobrero 2010; Block 2012; Chen and Hsu 2009). Moreover, the results show that the family owners' interpretation of, and reaction to, negative and positive performance feedback are also shaped by the underdeveloped property rights protection regime in China.

Theoretically, this study contributes to the debate on the heterogeneity of family firms by exploring the boundary conditions that need to be applied to the family firm strategic risk- 
taking framework largely developed and tested in institutional contexts characterized by welldeveloped legal systems. We document that both traditional agency theory and the behavioural agency model play a role in explaining Chinese family firm behaviour. The SEW framework is increasingly adopted to examine family firm decision-making and behaviours (Gómez-Mejía et al. 2007; Chrisman and Patel 2012), but is still evolving and our evidence from the largest emerging economy may provide new insights on the development of family firm theory around the globe. Our findings highlight a distinct pattern of R\&D behaviours among Chinese family firms suggesting the importance of considering the interaction between firm-level structure and governance and the macro-governance environment (Chen 2007). This sheds light on the impact of positive performance feedback that may be interpreted differently in diverse institutional environments. In practical terms, the study draws attention to institutional constraints that influence organizational outcomes for Chinese organizations and policy-makers.

The paper is structured as follows. Section 2 addresses the theoretical background and proposes the hypotheses. Section 3 describes the sample, variables and empirical models. The results are presented in Section 4 while Section 5 concludes and discusses future research avenues.

\section{THEORETICAL BACKGROUND AND HYPOTHESES}

\subsection{Socioemotional Wealth and the Strategic Behaviour of Family Firms}

Family firms are commonly defined by the influence exerted by a family and its vision of how the business should benefit the family across generations (Chua et al. 1999). This vision is likely to favour the adoption of family-centred goals (Chrisman et al. 2012) that lead family firms to embrace particularistic behaviours (that is, idiosyncratic behaviours compared to firms without family involvement; Chrisman et al. 2014; Chrisman and Patel 2012; De Massis et al. 2014; Habbershon, Williams, and MacMillan 2003; Gómez-Mejía et al. 2007). 
According to Gómez-Mejía and his colleagues, family-centred goals include the ability to exercise authority (Schulze, Lubatkin, and Dino 2003a), the possibility to be altruistic with family members (Schulze, Lubatkin, and Dino 2003b), the fulfilment of needs for identification (Gómez-Mejía et al. 2007) and the preservation of the family dynasty (Casson 1999). These goals create socioemotional wealth for the family, i.e., the stock of affectrelated value a family obtains from its ownership position in the firm (Gómez-Mejía et al. 2007). Preventing the potential loss of socioemotional wealth is considered a primary driver of family firm strategic decisions (Berrone et al. 2010; Gómez-Mejía et al. 2007; GómezMejía, Makri, and Larraza-Kintana 2010). Based on these premises, prior research consistently shows that family firms tend to downplay strategic actions such as $R \& D$ investments that may increase delegation or require diluting family control (Chrisman and Patel 2012; Munari et al. 2010; Chen and Hsu 2009).

Perhaps the most important feature that scholars emphasize to distinguish family and non-family firms is the family owners' intention for intra-family succession, which has a central role in existing theories of the family firm (Chrisman et al. 2003; Chrisman et al. 2012; Chua et al. 1999; Zellweger et al. 2012). The intentions for transgenerational family control lead family owners to attribute emotional value to the firm beyond its economic value (Zellweger et al. 2012). It follows that the intentions for transgenerational family control increase the salience of family-centred goals in decision-making (Chrisman et al. 2012) and reinforce the importance of emotional considerations of family owners in strategic decisions. However, not all family firms are willing or able to pursue family-centred goals (Chrisman et al. 2012, 2015; De Massis et al. 2014; De Massis, Di Minin and Frattini, 2015) and without such a vision, the nature of family-centred goals is likely to differ substantially (Chrisman et al. 2012). Prior research tends to take the existence of intentions for intra-family succession as granted and thereby overlooks the possibility that passing the business to the next 
generation of family members is sometimes constrained by the institutional environment, particularly by the legal protection of property rights. Family firms have been mostly studied in the North American and European context (De Massis et al. 2012) where legal systems strongly protect individual and property rights. By implication, most family business research rests on the implicit assumption that the coupling of ownership and control provides the family with legal rights over the firm's assets and future profits (Carney 2005; Gedajlovic, Lubatkin, and Schulze 2004). While this assumption holds in most western developed economies, it may be problematic for firms in China where more uncertain property rights and the risk of state intervention (e.g., predation or expropriation) are likely to change the position and aspirations of family owners. In a context where private property rights are uncertain, family owners are less likely to have intentions for intra-family succession, implying different goals and behaviours in these contexts.

What is more, studies applying the behavioural agency model suggest that the risk preferences of family owners and managers are not constant but change with the framing of problems (Wiseman and Gómez-Mejía 1998). Faced with a profound threat to socioemotional wealth, loss-averse family firms are likely to switch their policy towards risk-seeking preferences. In terms of $R \& D$ investments, Chrisman and Patel (2012) point to the great heterogeneity in family firm strategic behaviours, such that family firms generally invest less in $R \& D$ than non-family firms, increase their $R \& D$ investments when performance declines and further reduce R\&D investments when performance is above expectations. This literature points to an apparent logic guiding family firm strategic decisions that favours the preservation and transgenerational legacy of family control. Family firms are expected to increase risky long-term strategic actions such as $R \& D$ investments when performance declines and the risk of failure increases but be more conservative when socioemotional wealth is safe, as in the case of good performance. The conditions that may undermine 
socioemotional wealth have only been studied in contexts with strong property rights protection. The same performance feedback information can be interpreted differently in different institutional contexts such as China, although research has thus far not explicitly addressed this issue.

\subsection{Property Rights Protection in China}

In China, the Communist Party viewed wealth as the outcome of exploiting the poor and was thus considered undesirable. Chinese society has transitioned from a traditionally centralplanned economy to a market-oriented economy and private ownership re-emerged after the economic reform that began in 1978. In the last two decades, private firms have proliferated in China but uncertainty remains about the legal status of private firms and firm owners are concerned about possible policy reversals that could devalue their ownership (Walder 2009; Wang and Qian 2011; Lin 2011). Indeed, La Porta et al. (2004) rank China among the worst countries in terms of the security of property rights against infringement by the government, intended as the extent to which the government protects and enforces laws that protect private property, the probability that the government will expropriate private property and the country’s legal protection of private property (Holmes, Johnson, and Kirkpatrick 1997). In the same ranking, the United States and most western countries show a very strong property rights protection index.

The lack of clearly defined and routinely enforced private property rights is a major risk on family ownership in Chinese firms. In the absence of well-defined private property rights, family firms are vulnerable to unauthorized interference by redistributors who impose illicit charges on them, enforce regulations that may discriminate against private enterprises and restrict access to critical factor resources allocated by state agencies (Krug and Hendrischke 2008). For example, the government used to impose a limit on the number of workers private firms were allowed to hire (Nee 1992). The government and its officials may 
take advantage of their authority to intervene in private firms, e.g., forcing the appointment of directors with political backgrounds, achieving control of the firm and appropriating rents in the long run (Wang and Qian 2011; Fan et al. 2007). In short, the uncertainty of property rights increases the firm's discount rate, which lowers the present value of future cash flows generated by strategic activities such as R\&D investments.

Predation of the private sector is exacerbated in China by widespread corruption and government officials taking advantage of their political power to obtain personal rewards, which contribute to generating high uncertainty for the shareholders of non-state-owned firms. The owners of private companies fear that the government or its officials may challenge their rights to existing assets. Although class conflicts are no longer the case in China, a negative attitude towards the rich persists (Wang and Qian 2011). Several authors have shown that private Chinese firms need to carefully manage relationships with the government to establish legitimacy (Ahlstrom, Bruton, and Yeh 2008), obtain institutional support (Peng and Luo 2000; Xin and Pearce 1996) and access critical resources such as bank loans (Bai, Lu, and Tao 2006). These actions include cultivating relations with government officials, taking over failing state-owned enterprises, donating services to the local community and concealing the private nature of ownership (Ahlstrom et al. 2008). By implication, private firms in China have a considerable incentive to go unnoticed to avoid attracting the attention of government officials. As a result, it is not unusual for such firms to hide revenues and manage their earnings (Che and Qian 1998).

\subsection{Hypothesis Development}

According to the behavioural agency model, the adoption of family-centred goals is likely to affect the risk preferences of family firms, leading to avoiding decisions that may reduce the controlling family's socioemotional endowment (Berrone et al. 2010; Chrisman and Patel 2012; Gómez-Mejía et al. 2007). In particular, we focus here on R\&D investment behaviour. 
R\&D investments involve large resource commitments and considerable amounts of uncertainty due to the long-term horizon of returns and the difficulties related to adapting specialized assets to alternative uses, and are thus considered a pivotal dimension of strategic risk (Kor 2006; Holmes et al. 2011; Miller and Bromiley 1990). R\&D investments are also widely used to study risk-taking in family business literature (Chrisman and Patel 2012; Munari et al. 2010) as they have consequences on the controlling families' socioemotional wealth. First, increasing R\&D investments entails a higher risk of bankruptcy (Miller and Bromiley 1990). As Gomez-Mejia et al. (2010) note, bankruptcy also entails the loss of all socioemotional wealth associated with the family's control of the firm and the family's economic wealth. Second, as R\&D investments reduce the amount of resources freely available to managers, family managers are likely to see them as limiting their discretion. Third, increasing R\&D investments often requires diluting family control through increasing leverage or seeking external equity as family owners typically have limited funds due to their undiversified position in the firm (Schulze et al. 2001). Fourth, R\&D investments require adequate planning activities, which may in turn force family managers to disclose strategic information and cede authority to external professionals with the technical background and experience required to administer such activities (Miller and Cardinal 1994) and the consequent loss of family control over decision-making (Gómez-Mejía et al. 2010). Finally, in addition to threatening the family's unconstrained authority, increasing R\&D investments may also represent a hazard for the identity aspects of socioemotional wealth, which depend on the close identification of the family with the firm's products (Donnelley 1964). New product development typically involves external parties, which may weaken the connection between the family's name and the firm's products (Kotlar et al. 2013), while failure in developing new products may also erode the family name's reputation in the community (Dunn 1996). 
Taken together, these arguments suggest that family firms are likely to downplay R\&D investments, a hypothesis that finds broad empirical support among populations of firms in western developed countries (e.g., Chrisman and Patel 2012; Munari et al. 2010; Chen and Hsu 2009; Block 2012) ${ }^{1}$. This particularistic behaviour of family firms is primarily due to their inclination to preserve socioemotional wealth, yet for a controlling family to obtain non-economic returns in the form of socioemotional wealth requires certain assumptions on the protection of property rights that are often questionable in China. The Chinese context is characterized by weak protection of private property with no guarantee of continuing family control over generations and the additional risk of state intervention that leads family firms to find alternative routes to pursue their legacy. Thus, the choice of protecting socioemotional wealth through transgenerational family control is less attractive for family owners in China who are thus likely to consider alternative strategies to satisfy family needs. Instead of giving higher priority to the creation and preservation of SEW within the firm (Gómez-Mejía et al. 2011), family owners and managers in China may prefer to compensate for the uncertainty of their non-economic returns by maximizing financial benefits for themselves and the next generation family members, cashing out at will despite that this may jeopardize the firm's ability to generate profits in the future. Thus, the prediction that family firms will report lower $R \& D$ investments to protect SEW is inconceivable in a context of uncertain property rights such as China.

Rather, the differences in R\&D investments between family and non-family firms in China can be better understood if considering their distinct configurations of Type I and Type II agency problems and the state of corporate governance in China. Non-family firms generally experience a higher level of agency costs between owners and managers (i.e., Type I agency problem) than family firms (Berle and Means 1932; Jensen and Meckling 1976; La

\footnotetext{
${ }^{1}$ For a review of existing literature, see De Massis, Frattini and Lichtenthaler 2013.
} 
Porta et al. 1999; Schulze et al. 2003b). Therefore, the management in non-family firms tends to act myopically to obtain personal benefits such as higher value in the external labour market, but in so doing not acting in the best interests of shareholders (Narayanan 1985; Stein 1989; Shleifer and Vishny 1989; Bebchuk and Stole 1993). Worth noting moreover is that earnings management is widespread in China; prior studies show that Chinese firms manipulate earnings during the IPO process (Aharony et al. 2010) and continue to do so after the IPO either to avoid losses or report an increase over prior performance (Wang et al. 2008). Such earnings management may worsen as the development of China's capital markets unfolds; studies show that government policies or experiments actually induce additional earnings management behaviours (Hu et al. 2012). Family- and state-owned listed companies co-exist in China and the former are found more likely to engage in earnings management and thus provide lower quality accounting information (Ding et al. 2011). Furthermore, Chinese listed companies are found to use a variety of mechanisms such as transfer pricing for tax planning; when a firm faces a lower corporate income tax rate, its management shifts profit into the firm (Lo et al. 2010).

Well-publicized corporate scandals of Enron, WorldCom, Parmalat, and other companies led to numerous governance reforms in Western economies during the late 1990s and early 2000s, thereby increasing attention and scrutiny regarding the oversight of managers of public firms (e.g., Joseph, Ocasio, and McDonnell, 2014; Tihanyi, Graffin, and George, 2014). The Dodd Frank Act is just a recent example of measures aimed at improving governance structures in the United States, including enhanced disclosure requirements. However, Chinese corporate governance is at an earlier stage of development compared to the United States and most Western economies (Conyon and He, 2012) and the literature on tax manipulation in China (e.g., Liu and Xiao 2004) indicates that firms have strong incentives to lower taxes by hiding profits through manipulating expenses such as R\&D. 
Recent studies in the US also showed that American family firms are indeed less tax aggressive than their non-family counterparts (Chen et al. 2010). In the presence of weak property rights protection in China, this is especially important to family owners who may attempt to use R\&D expenses as a tax shield to extract economic benefits and avoid possible exploitation from the government or its officials. Indeed, R\&D expenditure is treated as an operating expense and can be used to artificially reduce firm earnings. The under-developed corporate governance practiced by listed Chinese companies leads to earnings management or even falsifying financial reports (Carney, Shapiro, and Tang 2009; Liu and Lu 2007; Clarke 2003), which provides family owners and managers the opportunity to obtain economic benefits and by manipulating $R \& D$ figures ensure the family wealth against possible government predation. Indeed, inside family owners have controlling power to expropriate minority shareholders while other large shareholders such as domestic institutional investors, foreign investors or other firms are less likely to extract private benefits from the firm and tend to bring stronger discipline and objectivity (e.g., Kim et al. 2008).

For these reasons, Chinese family firms are expected to have a higher level of reported R\&D expenses than non-family firms. Further support for this argument is provided by empirical studies showing that family firms have greater agency conflict between majority and minority shareholders (i.e., Type II agency problems) than non-family firms (Morck, et al. 1988, 1989; Shleifer and Vishny 1997). This is due to the existence of family-oriented controlling shareholders in family firms (Ding et al. 2011). Assuming that firms manipulate the reported R\&D expenses, family firms maintain more profit and the controlling shareholders as well as managers from the controlling family enjoy them by expropriating minority shareholders (Villalonga and Amit 2006). This is largely due to family owners generally having absolute and ultimate control of the board and the management team (Ding 
et al. 2011). Conversely, non-family firms are less willing to do so, or do so to a lesser extent, since their management teams and large shareholders are less likely to enjoy all the private benefits of hiding profits and are exposed to the risk of being caught and losing their reputation. This is rooted in the absence of shareholders with absolute control in Chinese non-family firms (Ding et al. 2011) and the lower incentives of non-family shareholders to extract private benefits from the firm (Kim et al. 2008). Indeed, institutional investors in emerging economies tend to have a short-term orientation due to the poor protection they receive (La Porta et al. 2000a).

Expropriation is a big concern in Chinese publicly listed firms. The China Security Regulatory Commission (CSRC), which is the counterpart of SEC in China, has set as its top priority the protection of minority shareholders. There is ample empirical evidence regarding such expropriation activities. Huyghebaert and Wang (2012), for instance, examine expropriation of minority shareholders in China and explore the role of several governance mechanisms in fighting against such expropriation. Their literature review highlights that a number of recent studies show that controlling shareholders in China expropriate minority shareholders by using related-party transactions and issuing loan guarantees to large shareholders. They further find that the ownership structure, board characteristics and China's imbalanced regional differences are among the factors that could moderate the extent of expropriation. Only weak evidence is provided on the role of high-quality institutions in curbing expropriation. Ding, et al. (2011) also find that, compared to non-family firms, family owners of family firms in China have stronger incentives to expropriate private benefits from minority shareholders. Facing an expropriation hazard from controlling shareholders, these outside investors may therefore prefer to obtain immediate gains through dividends (Kim et al. 2008; La Porta et al. 2000b, Shefrin and Statman 1984). Put differently, 
the private benefits generated by manipulating $R \& D$ expenses in Chinese non-family firms are diluted.

In sum, the weak certainty of property rights in China is likely to divert the interest of family owners from family-centred non-economic to family-centred economic goals, and given the role $\mathrm{R} \& \mathrm{D}$ expenditure plays in achieving extra economic utilities, we propose:

Hypothesis 1 (H1): In China, family firms are expected to report more $R \& D$ expenditure than non-family firms.

While the above arguments suggest a general tendency of family firms to report more $R \& D$ expenditure than non-family firms, the behavioural agency model further suggests that risk preferences are barely constant. Rather, firms set explicit performance aspiration targets and their behaviour changes according to whether performance is below or above this benchmark (Wiseman and Gomez-Mejia 1998). Thus, we expect the behaviour of family firms to be contingent upon the difference between performance aspirations and actual performance. The gap between performance and aspirations is assessed through historical or social comparisons (Cyert and March 1963). In a historical comparison, manager aspirations are typically modelled in terms of past performance (Cyert and March 1963). Instead, social comparison is related to industry averages, which serve as targets for the financial goals of many firms (Frecka and Lee 1983).

While the impact of negative performance feedback is extensively examined in prior studies on risk-taking behaviour in family firms (Chrisman and Patel 2012; Gómez-Mejía et al. 2010), no explicit hypotheses have thus far been proposed on how family firms respond to positive deviations in performance in relation to aspirations. This because, assuming secure property rights, researchers are more interested in negative performance feedback as a signal of the possible loss of SEW (Chrisman \& Patel 2012; Gomez-Mejia et al. 2010). Conversely, 
when performance feedback is positive, SEW is normally considered as safer. However, these contentions must be revised in the context of China as the weak protection of property rights changes the incentives of family owners and managers, and the interpretation of performance feedback by family owners and managers is therefore also likely to differ.

According to the behavioural agency model, positive performance feedback leads to even lower R\&D investments as firms become satisfied with the status quo and thus downplay problematic search behaviours (Wiseman and Gomez-Mejia 1998; Greve 2003; Cyert and March 1963). While the family goals and the economic goals of the firm converge when the performance gap is negative, family goals gain priority when economic goals are satisfied. Thus, family firms are expected to favour the preservation of SEW by reducing R\&D investments when facing positive performance feedback (Chrisman and Patel 2012).

However, the effect of positive performance feedback on R\&D expenses reported by Chinese family firms is expected to be different due to the institutional context. As previously mentioned, family firms in China are likely to maximize their financial wealth and family owners are likely to use their dominant position in the firm to extract private benefits at the expense of minority shareholders. In other words, they have stronger incentives to manipulate their $R \& D$ expenses than their non-family counterparts due to the greater agency conflict between majority and minority shareholders (i.e., Type II agency problems). Inside owners such as family members have controlling power to expropriate minority shareholders whereas outside owners, such as domestic institutional investors, foreign investors or other firms can bring stronger discipline and objectivity to the decision-making process (e.g., Kim, Kim, and Lee 2008). Their focus on economic utilities is hypothesized in $\mathrm{H} 1$ and Chinese family firms are expected to report higher $R \& D$ expenses. However, the incentives for controlling families faced with positive performance feedback are twofold. 
On one hand, a positive gap between performance and aspirations may signal a successful R\&D strategy thus leading to more R\&D. Financial success may also provide more resources for R\&D since family firms are less likely to use external financing for this activity (Chrisman and Patel 2012; Chen and Hsu 2009). Furthermore, the continuing incentive to engage in possible exploitation and entrenching activities means family firms use R\&D as a possible coping mechanism, also to reduce the tax burden. Therefore, improved performance in family firms may lead to reporting even greater R\&D expenses. We thus propose:

Hypothesis 2a (H2a): In China, the relationship between family involvement and reported $R \& D$ expenses is moderated by improving performance such that family firms will further increase $R \& D$ expenses when performance is improved.

On the other hand, the socio-political environment in which Chinese family firms operate may make them reconsider their R\&D strategy. Family firms investing more in R\&D in financially successful periods may easily stand out, resulting in additional and significant costs. Family firms may therefore slow down their R\&D investments despite improving financial performance. Family ownership in China is insecure as the government and its officials may impose illicit charges and threaten the firm by restricting access to critical resources. Family owners are thus likely to be very careful about their image and relationship with the government (Ahlstrom et al. 2008; Peng and Luo 2000; Xin and Pearce 1996; Bai et al. 2006). In addition to the negative attitude towards the rich that persists in Chinese society (Wang and Qian, 2011), the threat of state intervention is likely to be perceived more strongly by family owners when a firm gains visibility. 
More specifically, several factors may lead Chinese family firms faced with positive performance feedback to reduce reported R\&D expenses. First, in political terms, financially successful family firms could be asked by the government to fulfil extra social responsibilities such as poverty alleviation, excessive donations and face potential extortion. These political obligations may turn into a considerable economic burden. Second, in economic terms, such firms could be targeted by the tax authorities due to widespread unethical or illegal tax filing practices. An examination by the tax authority may lead to a higher tax burden in the future and in the worst-case scenario to a criminal investigation. Third, in social terms, family firm owners of successful and exponentially expanding firms may attract media attention. Fortune's Wealthiest Chinese List in Mainland China, for instance, provides an annual ranking of the rich, including family firm owners. Ironically, the richest in China have tried to avoid such media exposure, as there are numerous cases of the former rich who are now behind bars. Last but not least, in cultural terms, the dominance of Confucianism in China motivates firm owners to take a balanced approach to firm growth. Such owners may slow down their R\&D pace despite improving financial performance and abundant resources. For these reasons, we propose the following alternative hypothesis on the moderating effect of positive performance feedback on the relationship between family involvement and R\&D investments:

Hypothesis $2 \boldsymbol{b}$ (H2b): In China, the relationship between family involvement and reported $R \& D$ expenses is moderated by improving performance such that family firms will decrease $R \& D$ expenses when performance is improved.

As stated, prior research has focused relatively more on the impact of negative performance feedback (e.g., Chrisman and Patel 2012; Gómez-Mejía et al. 2010). When faced with declining performance (i.e., performance below aspirations), managers are generally expected 
to frame problems as opportunities and pursue projects that increase outcome variance, but also with the potential benefit of recovering the firm's competitive advantage since projects with lower variance are likely to preserve the status quo (Singh 1986; Bromiley 1991; Chen 2008). Prior studies assume secure property rights and under this assumption, R\&D investments are expected to be kept low in family firms as they may be seen as a threat to the controlling family's socioemotional wealth. However, as Gomez-Mejia et al. (2010) and Chrisman and Patel (2012) note, family goals are likely to converge with firm economic goals when the risk of failure, which becomes manifest when performance declines, increases. Indeed, family firms are characterized by high ownership concentration and family wealth is typically undiversified (for the most part invested in the family firm), suggesting that if the firm does not survive, all the family's economic and socioemotional wealth will be lost (Gómez-Mejía et al. 2010). For this reason, behavioral agency theory suggests that declining performance is likely to alarm managers in family firms even more than in non-family firms, and the former are thus expected to increase R\&D investments more than the latter when observing negative performance gaps (Chrisman and Patel 2012).

However, in China, due to the particular socio-political environment, declining performance may not have the same impact on the strategic decisions of family firms. According to $\mathrm{H} 1$, the institutional context makes family owners insecure about obtaining SEW in the form of continued control of the firm; control preservation therefore plays a less important role in decision-making. Since preserving the family's SEW does not emerge as a top priority for Chinese family firms, their R\&D strategy is less likely to be affected by declining performance, even if deteriorating performance may threaten long-term SEW. Consistent with our arguments leading to H1, R\&D expenses could be used by the controlling family to extract private rents. Controlling families obtains economic benefits in the form of expropriating minority shareholders (Ding et al. 2011) since corporate governance in Chinese 
firms is shown to be under-developed; the overall governance mechanisms need to improve to curb the agency problems between controlling and minority shareholders. Family firm rent-seeking intentions, in conjunction with the possibility of tunneling and earnings management practices (Liu and Lu 2007), may make such firms maintain their R\&D intensity. Therefore, family firms in China are expected to be less susceptible to potential threats to SEW and maintain their positive attitude toward R\&D expenses even when their performance deteriorates. It follows that positive and negative performance feedback exerts an asymmetric moderation effect on the relationship between family involvement and R\&D investments. We thus propose:

Hypothesis 3 (H3): In China, declining performance does not moderate the relationship between family involvement and $R \& D$ expenses such that family firms will maintain their higher $R \& D$ expenses even when faced with declining performance.

\section{METHODOLOGY}

To test the three hypotheses proposed in Section 2, we formed a sample consisting of nonstate-owned firms operating in all industries except financial services and utilities. The sample period is 2006 to 2010, since 2006 was the first year in which R\&D-related information on firms listed in China's two markets became available. The sample for this study includes information on R\&D investments, family involvement in both ownership and management, accounting items adopted by previous studies in this stream of literature and stock market performance. The sources of our data are GuoTaiAn (GTA) and annual reports filed by publicly listed companies with the China Securities Regulatory Commission (CSRC) during the sample period. Studies based on databases provided by GTA such as those of Wei, Xie, and Zhang (2005), Haw, Qi, Wu, and Wu (2005), Kato and Long (2006), Ding et al. 
(2011) and Cumming and Hou (2014) have been published in leading management, finance and accounting journals. Based on the availability of information, the sample formed to test the three hypotheses consists of 402 firm-year observations ${ }^{2}$ and provides robust results given the quality and richness of the information provided.

The dependent variable is $R \& D$ intensity (RDI) measured by the ratio between $R \& D$ expenses and total sales. For the robustness check we also consider RDI measured by R\&D expenses as a portion of the book value of total assets. This is consistent with previous studies such as Chrisman and Patel (2012) and Munari et al. (2010).

As we place emphasis on how family involvement affects firm R\&D-related behaviours, we form the independent variable by taking into consideration both family ownership and family management. In addition to family involvement, family firms are defined as firms with a particularistic vision of business and goals resulting from the presence of a controlling family (Chua et al. 1999). A direct measure of family vision and goals is not available for these publicly listed companies. This is a common problem that prior research has typically obviated by assuming that family vision and goals are highly correlated to the extent of family involvement in the firm (e.g., Gomez-Mejia et al. 2010). This assumption has also received empirical validation (e.g., Chrisman et al. 2012, Chrisman and Patel 2012). This study therefore adopts an objective measure of family influence and relies on the dimensions of family involvement in ownership and management using a similar approach to Chrisman and Patel (2012). For our purposes, we use a binary variable that distinguishes family firms (=1) from non-family firms (=0) based on family ownership and family involvement in management (e.g., Anderson and Reeb 2003; Chrisman and Patel 2012; Villalonga and Amit 2006). The GTA data set defines a firm as family owned if that firm is

\footnotetext{
${ }^{2}$ The small sample size is mainly due to missing values of R\&D expenses, although the original sample size of non-state-owned firms listed in Chinese markets was 3,744. Additional tests were conducted to check potential sample selection bias and the reliability of the empirical results has been proven.
} 
ultimately controlled by a private person and his or her family, and this definition is similar to what has been adopted by Ding et al. (2011). Since the capital market in China has a relatively short history, most, if not all, family firms in our sample are still owned and operated by the first generation of families, suggesting that families are extensively involved in the business. Therefore a family firm is defined in our study as a firm that has a family as the ultimate controller and that has family members serving on the board and management.

We constructed the moderating variables - performance aspiration gaps with respect to historical and competitor return on assets (ROA) - following prior research such as McConnell and Servaes (1990), Chen (2008), and Chrisman and Patel (2012). To assess the performance aspiration gaps, we first estimated the difference in historical ROA of a firm between Years t-1 and t-2 as well the difference between the firm's ROA and the average ROA of the industry in which it operates. We then calculated the absolute values of these performance aspiration gaps and created four performance-aspiration-gap variables, either left-censored or right-censored: Performance Below Historical Aspiration Level, Performance Above Historical Aspiration Level, Performance Below Industry Aspiration Level, and Performance Above Industry Aspiration Level. To test $\mathrm{H} 2$ and H3, we also created the interactions between family involvement and these performance aspiration gaps.

Applying the same approach as previous studies on R\&D investments (Chen and Hsu 2009; Chrisman and Patel 2012), we chose control variables in Year t-1 such as ROA, firm size measured by the natural logarithm of total sales, firm age based on the year in which the firm was founded, Tobin's Q measured by the market-to-book ratio, and Altman's z-score to capture accounting and market performance and firm characteristics. Following Singh (1986) and Chrisman and Patel (2012), we also include three variables measuring absorbed, unabsorbed and potential slack. The absorbed slack estimates the proportion of total sales spent on selling, general and administrative expenses. The unabsorbed slack characterizes the 
liquidity using the ratio between current assets and current liabilities. The potential slack captures the nature of a firm's financing structure using its debt-to-equity ratio. One interesting issue is the existence of non-tradable shares in Chinese markets (Firth, Fung, and Rui 2006, 2007; Luo et al. 2013). Therefore, as Chen and Xiong (2001) propose, we calculated Tobin's Q by taking into consideration the existence of non-tradable shares in China's stock exchanges and by excluding the non-tradable shares, using both for robustness tests.

To control for year and industry effects, we also included 5 year dummies and 12 industry dummies based on 4-digit GICS (Global Industry Classification Standard). To deal with potential endogeneity concerns between $R \& D$ expenses and family involvement (Chrisman and Patel 2012), we chose the dummy variable CRISIS as the instrumental variable $^{3}$, which has a value of 1 if a firm-year observation is in a year after the ongoing financial crisis started and zero otherwise. This indicates the characteristics of information transparency and private benefit extraction, and statistically serves as a valid instrument. The empirical models used to test H1-3 are the following:

$$
\begin{aligned}
& \mathrm{RDI}_{t}=\alpha_{1}+\alpha_{2} \text { ROA }_{t-1}+\alpha_{3} \text { FirmSize }_{t-1}+\alpha_{4} \text { FirmAge }_{t-1}+\alpha_{5} \text { Tobin }_{t-1} \\
& +\alpha_{6} \text { AltmanZ }_{t-1}+\alpha_{7} \text { Absorbed Slack }_{t-1}+\alpha_{8} \text { Unabsorbed Slack }_{t-1} \\
& +\alpha_{9} \text { Potential Slack }{ }_{t-1}+\alpha_{10} \text { Year Dummies } \\
& +\alpha_{11} \text { Industry Dummies }+\epsilon_{1} \\
& \mathrm{RDI}_{t}=\beta_{1}+\beta_{2} \text { Performance Aspiration Gaps }+\beta_{3} \text { Control }+\epsilon_{2}(2) \\
& \mathrm{RDI}_{t}=\theta_{1}+\theta_{2} \text { Family Involvement }+\theta_{3} \text { Control }+\epsilon_{3}(3) \\
& \mathrm{RDI}_{t}=\eta_{1}+\eta_{2} \text { Family Involvement }+\eta_{3} \text { Performance Aspiration Gaps } \\
& +\eta_{4} \text { Control }+\epsilon_{4}(4) \\
& \mathrm{RDI}_{t}=\gamma_{1}+\gamma_{2} \text { Family Involvement }+\gamma_{3} \text { Performance Aspiration Gaps }
\end{aligned}
$$

\footnotetext{
${ }^{3}$ The validity of this instrumental variable was tested.
} 
$+\gamma_{4}$ Family Involvement $\times$ Performance Aspiration Gaps $+\gamma_{5}$ Control $+\epsilon_{5}(5)$

where the control variables in Equations (2)-(5) are the same as those in Equation (1).

According to $\mathrm{H} 1, \theta_{2}, \eta_{2}$, and $\gamma_{2}$ are expected to be positive and significant. H2a predicts the coefficients on "Family Involvement $\times$ Performance Above Historical Aspiration Level" and "Family Involvement $\times$ Performance Above Industry Aspiration Level” to be significantly positive, while $\mathrm{H} 2 \mathrm{~b}$ predicts these to be significantly negative. As predicted in H3, the coefficients on "Family Involvement $\times$ Performance Below Historical Aspiration Level" and "Family Involvement $\times$ Performance Below Industry Aspiration Level" are expected to be insignificant.

\section{RESULTS}

\subsection{Descriptive Statistics}

As noted before, our sample comprises 402 firm-year observations ${ }^{4}$ and all are non-stateowned companies listed in China's two markets. These 402 observations include 246 familyfirm and 156 non-family-firm observations. In other words, 61.2 percent of observations are from family firms. The detailed descriptive statistics are presented in Panel A of Table 1. On average, non-state-owned listed firms in China spent 2.4 percent of their sales revenues on R\&D. However, family firms are found to invest more in $R \& D$ than their non-family counterparts: 2.9 percent versus 1.6 percent with a $t$ - value of 2.607 , which is significant at the 1 percent level. For reasons of space, we do not repeat the descriptive statistics in Panel A of Table 1 but highlight some significantly different variables between family and non-family firms. For instance, family firms are significantly (at the 1 percent level) younger than nonfamily firms. When considering market performance measured by Tobin’s Q, family firms

\footnotetext{
${ }^{4}$ Since many companies did not disclose their R\&D data, our sample size dropped significantly. To address concern over possible systematic differences between disclosers and non-disclosers, we did additional tests to show if the two groups are different. We compared the means between the groups for a variety of firm characteristics and ownership, but did not find significant differences in general.
} 
outperform non-family firms at the 5 percent significance level. In terms of accounting performance, we find that the ROA and Altman's Z-score of family firms are higher than those of non-family firms and both are significant at the 10 percent level. Last, family firms tend to be larger than non-family firms when firm size is measured as total sales; the difference is significant at the 10 percent level.

(INSERT Panels A and B of TABLE 1 ABOUT HERE)

Due to the large number of missing values of R\&D expenses, we follow Grullon, Kanatas, and Weston (2004) to conduct compare-mean $t$-tests between our sample firms and those that have missing values of R\&D expenses. The comparison is presented in Panel B of Table 1, and indicates that our sample firms have similar accounting and market performance, firm age, Altman's Z-Score, absorbed slack, and potential slack to those firms with missing values of R\&D expenses. However, our sample firms tend to be larger and have more unabsorbed slack than the rest of the population. Overall, these results show that our sample is unbiased from the population, even if it only consists of firms with data of R\&D expenses available.

\subsection{Hypothesis Testing}

We predict in $\mathrm{H} 1$ that Chinese family firms may pursue non-economic utilities to a lesser extent but have more incentives to manipulate R\&D expenses for profit-hiding purposes due to China's macro environment characterized by insufficient property rights protection. That is to say, Chinese family firms promote financial wealth maximization and the creation of economic utilities for their future generations and have stronger incentives to exploit minority shareholders with various approaches such as inflating R\&D expenses. As a result, we predict that Chinese family firms report more in R\&D expenses than their non-family counterparts. 
H1 is not rejected; the supporting evidence based on Equations (1)-(5) is presented in Table 2. After controlling for other factors that could affect a firm's R\&D investment intensity, we find, as predicted, that Chinese family firms report more than their non-family counterparts. This is statistically significant as shown by the $t$-value of 2.75 demonstrating 1 percent significance while the economic significance of the family-involvement effect is 1.6 percent of firm total sales. This finding suggests that Chinese family firms are motivated to maximize the market value of their firms while placing lower priority on SEW preservation and are likely to manipulate R\&D expenses to a greater extent ${ }^{5}$.

When family firm performance is above a benchmark, whether a historical or competitive aspiration level (Chrisman and Patel 2012), we predict in H2a that improved performance leads family firms in China to further increase their R\&D expenses and in $H 2 b$ that it leads to decreasing their R\&D expenses. The results are presented in Table 2. As can be seen from the last column, the coefficient of the interactive term "Family Involvement $x$ Performance Above Historical Aspiration Level” is significantly negative with a coefficient of -0.174 , which is significant at the 5 percent level. In contrast to $\mathrm{H} 2 \mathrm{a}$, this finding suggests that Chinese family firms reduce R\&D expenses more than their non-family counterparts when there is a positive gap between aspiration and performance. $\mathrm{H} 2 \mathrm{~b}$ is therefore not rejected. This means that between the two forces of different directions, the institutional impact on Chinese family firm behaviours dominate over economic behaviours rooted in the long-term orientation. We also plot the interaction in a graph as shown in Figure 1.

\section{(INSERT FIGURE 1 ABOUT HERE)}

As performance declines, family firms may have to shift their focus from SEW preservation, if any, to financial performance since declining performance threatens firm

\footnotetext{
${ }^{5}$ National culture may also lay a role here but is outside the scope of this study.
} 
survival; when firms fail to survive, the family may lose its overall SEW (Gómez-Mejía et al. 2007; Gómez-Mejía et al. 2011; Chrisman and Patel 2012). However, in the context of China, the pursuit of SEW by family firms is lower due to uncertain property rights, we thus hypothesize that negative performance feedback will leave the R\&D behaviour of Chinese family firms unaltered. We therefore predict in $\mathrm{H} 3$ that the Chinese family firm R\&D strategy will not be moderated by declining performance. The empirical results presented in the last column of Table 2 provide support for this hypothesis; neither the coefficient on the interactive term “Family Involvement $\times$ Performance Below Historical Aspiration Level” nor that on "Family Involvement $\times$ Performance Below Industry Aspiration Level" are statistically significant.

These findings are plausible as family firms in China consider SEW preservation to a lesser extent due to the distinct environment in which they are imbedded. SEW does not become a dominant decision-making framework and there is therefore no case of a family firm shifting focus from SEW to financial performance. In other words, family firms in mature markets with effective property rights protection always promote SEW such that in financially difficult times they temporarily shift their focus hoping to preserve SEW in the long run. However, Chinese family firms always have financial value maximization as their primary if not only focus. As a result, when a new situation such as financial difficulty emerges as a threat to long-term SEW preservation, the lack of attention to SEW in the first place means it is less likely to affect such firms’ R\&D. Therefore, as predicted, declining performance does not moderate the relationship between family control and R\&D expenses in China.

\subsection{Robustness Tests}

We ran a variety of analyses to ensure our results are robust to different model specifications; the robustness tests are presented in Table 3. Our results suggest that the empirical findings 
presented in the hypotheses testing are not sensitive to different variable measurement and model specifications. First, we follow Chrisman and Patel (2012) considering the possible endogeneity of family control. The inverse Mill's Ratio (IMR) is not significant in the second stage, suggesting that endogeneity concern does not bias our estimation. Furthermore, after adding IMR in the second stage, our results remain unchanged. These are presented in the last two columns of Table 3. Second, when taking into account only part of the performance aspiration gaps, as presented in the first four columns of Table 3, no qualitative change was found. Third, as mentioned earlier, we also took the existence of non-tradable shares in China markets into consideration while calculating alternative control variables such as Tobin's Q, but did not find any qualitative changes. Fourth, we also used another measure of $R \& D$ intensity - the ratio between R\&D expenses and book value of total assets - to replace the dependent variable (R\&D intensity measured by $R \& D$ expenses-total sales ratio) but no qualitative change was found. Fifth, as R\&D expenses are highly industry sensitive, we used industry-adjusted $R \& D$ expenses as a scale of total sales to rerun all the tests for the results presented in Table 2 and no qualitative change was found. These results are not tabulated for reasons of space but are available on request.

\section{(INSERT TABLE 3 ABOUT HERE)}

We also follow previous studies, such as Chi and Lee (2010) and Hovakimian and Li (2011, 2012), to replace missing values of R\&D expenses with zeroes and redo the tests. The main family effect still exists and is even stronger, so that $\mathrm{H} 1$ is not rejected. However, none of the interactions between family involvement and historical/competitive aspiration levels significantly impacts firm’s R\&D expenses.

\subsection{Comparison with Results from Other Contexts}


Family business literature shows that family firms are not only driven by economic performance but their behaviours often differ from non-family firms due to family firms pursuing and preserving the family's socioemotional wealth. The creation and preservation of the family's SEW requires effective intergenerational control and smooth intra-family succession, but such family control and succession can only arise from proper property rights protection. In contrast to western developed economies, China has uncertain property rights that demotivate family firms in China from pursuing these non-economic goals. As a result, we expect that China's macro socio-political environment characterized by uncertain property rights leads these family firms to adopt different coping mechanisms compared to their nonfamily counterparts. In the context of R\&D, we expect different patterns of $R \& D$ strategies to emerge from Chinese family firms. Our findings confirm our arguments.

First, in developed economies such as the U.S., family involvement lowers R\&D investment (e.g., Chrisman and Patel 2012; Block 2012) as family firms are concerned that their R\&D investment may jeopardize the preservation of their family's SEW. We show that in China, this relationship is completely the opposite such that family involvement increases R\&D expenses. Second, in the U.S. market, "family firms increase R\&D investments more than non-family firms when the gap between aspirations and performance is negative" (Chrisman and Patel 2012, 981). In China, however, family firm R\&D expenses are not at all affected by declining performance. In other words, declining performance fails to serve as a meaningful moderator in the context of R\&D in China. Third, in the U.S. market, family firms further lower R\&D investments when firm performance is above the aspiration level (Chrisman and Patel 2012). In China, however, family firms tend to increase R\&D expenses more than non-family firms when they have sound performance. Table 4 summarizes the sharp contrast between existing evidence based on U.S. family firms and our findings based on Chinese family firms. 
(INSERT TABLE 4 ABOUT HERE)

\section{CONCLUSIONS AND FUTURE RESEARCH}

Researchers have extensively examined whether and how family involvement affects family firm decision-making and behaviour. The Gomez Mejia et al. (2011) review shows that family firms behave differently than non-family firms to preserve the family's socioemotional wealth. Numerous studies find that whether SEW is explicitly mentioned or not, family involvement affects family firm management processes, strategic choices, organizational governance, stakeholder relationships and business venturing (Gómez-Mejía et al. 2011). A number of studies document that consistent with the SEW preservation framework, family firms invest less in R\&D as a key strategic decision (Chrisman and Patel 2012). Significant insight notwithstanding, findings from these studies using family firms in mature economies may not be generalized to China, a typical emerging market in which family firms are developing exponentially and where property rights protection is still evolving. Our study examines Chinese family firm R\&D investments to shed light on the different coping strategies of these firms in their distinct socio-political environment.

Our analyses of the operating environment of Chinese family firms lead us to predict that family involvement in China may result in an entirely different strategy to deal with R\&D investments such that they maximize economic wealth rather than non-economic goals. Their incentive to maximize economic utilities and exploit benefits from minority shareholders leads us to predict that Chinese family firms may report more R\&D expenses. Our findings confirm our prediction; Chinese family firms report more R\&D than their nonfamily counterparts. Furthermore, we present supporting evidence on the role played by improving performance, consistent with our analyses of the decision-making context facing Chinese family firms. Our findings also answer the question of how declining performance affects Chinese family firm R\&D in view of the very distinct environment. 
Our study thus contributes to the accumulating evidence of family firm heterogeneity, the application of traditional agency theory and the SEW framework in family firm research and R\&D literature. Most importantly, our research suggests that family firm attitudes towards R\&D investments change across institutional contexts, thus pointing to meaningful cross-national variations in family firm behaviours, and identifying property rights protection as an important boundary condition to be considered in studies using behavioural theory to predict organizational processes and outcomes.

Aside from its contributions, this study has several limitations. First, due to data unavailability, we were unable to examine the association between family involvement and R\&D using all non-state controlled firms since the key R\&D investment variable was not disclosed for some firms in our sample period. As a result it is interesting for future studies to examine if family involvement affects disclosure decision of these firms in the first place ${ }^{6}$. Second, the stock market in China was not established until the 1990s and as a result, listed Chinese family firms are much younger than their counterparts in western markets. Ownership concentration also differs between the U.S. and China; caution needs to be exercised in drawing implications by comparing our study with existing studies using family firms from different markets. Lastly, some other factors are expected to influence firm R\&D, such as corporate espionage ${ }^{7}$, and therefore need to be controlled for. However, such data are not available in our dataset and further studies could examine such impact where data are available.

Our findings on Chinese family firm R\&D behaviour are consistent with existing studies on firms with family involvement in China (e.g., Ding et al. 2011). The findings from these studies convincingly highlight that Chinese family firms promote SEW preservation to a lesser extent. Given the multiple dimensions that SEW incorporates (Berrone et al. 2012),

\footnotetext{
${ }^{6}$ We thank the Associate Editor for raising this point.

${ }^{7}$ We thank an anonymous referee for raising this point.
} 
future studies could further examine if family firms in China act to preserve SEW in other dimensions such as capital expenditure and diversification. Capex investments could be influenced by accounting standards, but for jurisdictions with the same GAAP (Generally Accepted Accounting Standards) important insight could be obtained from examining family firm capex across countries with the same accounting regulations. The EU, for instance, switched to IFRS (International Financial Reporting Standards) in 2005, while China has been converging towards IFRS. As a result, future studies could use the EU and China as a research setting to examine how family firms differ from their non-family counterparts in terms of capex, providing interesting comparative evidence ${ }^{8}$. In view of the continuing reforms of China's political and legal systems, future studies could shed light on how the evolving macro governance environment affects family firm decision-making and behaviours. In addition, despite the relatively young age of Chinese family firms, many are experiencing intra-family succession. It would be interesting to see if the second generation of Chinese family firms views SEW preservation differently. Also, separating potentially manipulated $R \& D$ expenses from the $R \& D$ investments of Chinese firms would provide the opportunity to re-test the effects of family involvement on these two components. Finally, our study has focused on R\&D investments, which are an input to the innovation activities of a firm. However, lower R\&D investments do not necessarily result into lower innovation outputs in family firms (Duran et al., 2015). In this respect, some family firms are able to access unique resources, such as their tradition, to innovate (De Massis et al., 2016b), and are able to be extremely innovative while preserving their strong family character (De Massis et al., 2016a). Unfortunately, we know little about the drivers of innovation performance in Chinese family firms, which represents a further important area for future research.

\footnotetext{
${ }^{8}$ We thank an anonymous referee for raising this point.
} 


\section{REFERENCES}

Aharony, J., J. Wang, and H. Yuan. 2010. Tunneling as an incentive for earnings management during the IPO process in China. Journal of Accounting and Public Policy 29: 1-26.

Ahlstrom, D., G.D. Bruton, and K.S. Yeh. 2008. Private firms in China: Building legitimacy in an emerging economy. Journal of World Business 43(4): 385-399.

Anderson, R.C., and D.M. Reeb. 2003. Founding-family ownership and firm performance: Evidence from the S\&P 500. Journal of Finance 58(3): 1301-1327.

Bai, C.E., J. Lu, and Z. Tao. 2006. Property rights protection and access to bank loans. Economics of Transition 14(4): 611-628.

Bebchuk, L.A., and L.A. Stole. 1993. Do short-term objectives lead to underinvestment or overinvestment in long-term projects? Journal of Finance 48: 719-729.

Berle, A.A., and G.C. Means. 1932. The Modern Corporation and Private Property. New York: Harcourt, Brace \& World.

Berrone, P., C. Cruz, and L.R. Gomez-Mejia. 2012. Socioemotional Wealth in Family Firms: Theoretical Dimensions, Assessment Approaches, and Agenda for Future Research. Family Business Review.

Berrone, P., C. Cruz, L.R. Gomez-Mejia, and M. Larraza-Kintana. 2010. Socioemotional Wealth and Corporate Responses to Institutional Pressures: Do Family-Controlled Firms Pollute Less? Administrative Science Quarterly 55(1): 82-113.

Block, J.H. 2012. R\&D investments in family and founder firms: An agency perspective. Journal of Business Venturing 27(2): 248-265.

Bromiley, P. 1991. Testing a causal model of corporate risk taking and performance. Academy of Management Journal 34(1): 37-59.

Carney, M. 2005. Corporate governance and competitive advantage in family-controlled firms. Entrepreneurship Theory and Practice 29(3): 249-265.

Carney, M., D. Shapiro, and Y. Tang. 2009. Business group performance in China: Ownership and temporal considerations. Management and Organization Review 5(2): 167-193.

Casson, M. 1999. The economics of the family firm. Scandinavian Economic History Review 17(1): 10-23.

Che, J., and Y. Qian. 1998. Insecure property rights and government ownership of firms. The Quarterly Journal of Economics 113(2): 467-496.

Chen, H.L., and W.T. Hsu. 2009. Family ownership, board independence, and R\&D investment. Family Business Review 22(4): 347.

Chen, S., Chen, X., Cheng, Q., and Shevlin, T., 2010. Are family firms more tax aggressive than non-family firms? Journal of Financial Economics 95: 41-61. 
Chen, W. 2007. Does the colour of the cat matter? The red hat strategy in China's private enterprises. Management and Organization Review 3(1): 55-80.

Chen, W.R. 2008. Determinants of firms' backward-and forward-looking R\&D search behavior. Organization Science 19(4): 609-622.

Chen, Z., and P. Xiong. 2001. Discounts on illiquid stocks: Evidence from China. Yale ICF working paper No. 00-56.

Chi, J.D., and D.S. Lee. 2010. The conditional nature of the value of corporate governance. Journal of Banking \& Finance 34(2): 350-361.

Chrisman, J.J., H. Fang, J. Kotlar, and A. De Massis. 2014. A Note on Family Influence and the Adoption of Discontinuous Technologies in Family Firms. Journal of Product Innovation Management In press, DOI: 10.1111/jpim.12206.

Chrisman, J.J., and P.J. Patel. 2012. Variations in R\&D Investments of Family and Nonfamily Firms: Behavioral Agency and Myopic Loss Aversion Perspectives. Academy of Management Journal 55(4): 976-997.

Chrisman, J.J., J.H. Chua, A. De Massis, F. Frattini, and M. Wright. 2015. The ability and willingness paradox in family firm innovation. Journal of Product Innovation Management 32(3): 310-318.

Chrisman, J.J., J.H. Chua, A.W. Pearson, and T. Barnett. 2012. Family Involvement, Family Influence, and Family Centered Non Economic Goals in Small Firms. Entrepreneurship Theory and Practice 36(2): 267-293.

Chrisman, J.J., J.H. Chua, and R. Litz. 2003. A unified systems perspective of family firm performance: An extension and integration. Journal of Business Venturing 18(4): 467472.

Chua, J.H., J.J. Chrisman, and P. Sharma. 1999. Defining the family business by behavior. Entrepreneurship Theory and Practice 23(4): 19-39.

Chua, J.H., J.J. Chrisman, and A. De Massis. 2015. A Closer Look at Socioemotional Wealth: Its Flows, Stocks, and Prospects for Moving Forward. Entrepreneurship Theory \& Practice 39(2): 173-182.

Clarke, D. 2003. Corporate governance in China: An overview. Working paper, University of Washington. Available at SSRN 424885.

Conyon, M.J., and L. He. 2012. CEO compensation and corporate governance in China. Corporate Governance: An International Review, 20(6): 575-592.

Cumming, D., and W. Hou. 2014. Valuation of restricted shares by conflicting shareholders in the Split Share Structure Reform. European Journal of Finance 20(7-9): 778-802.

Cyert, R.M., and J.G. March. 1963. A behavioral theory of the firm, Englewood Cliffs, NJ: Prentice-Hall.

De Massis, A., A. Di Minin, and F. Frattini. 2015. Family-driven innovation: Resolving the ability and willingness paradox to unlock the innovation potential of family firms. California Management Review. In press. 
De Massis, A., F. Frattini, and U. Lichtenthaler. 2013. Research on Technological Innovation in Family Firms: Present Debates and Future Directions. Family Business Review, 26(1): 10-31.

De Massis, A., J. Kotlar, J.H. Chua, and J.J. Chrisman. 2014. Ability and Willingness as Sufficiency Conditions for Family-Oriented Particularistic Behavior: Implications for Theory and Empirical Studies. Journal of Small Business Management 52(2): 344364.

De Massis, A., J. Kotlar, F. Frattini, J.J. Chrisman, and M. Nordqvist. 2016a. Family governance at work: Organizing for new product development in family SMEs. Family Business Review, in press.

De Massis, A., J. Kotlar, F. Frattini, A, Petruzelli, and M. Wright, M. 2016b. Innovation through tradition: Lessons from innovative family businesses and directions for future research. Academy of Management Perspectives, in press.

De Massis, A., P. Sharma, J.H. Chua, J.J. Chrisman, and J. Kotlar. 2012. State-of-the-art of family business research. In De Massis, A., P. Sharma, J.H. Chua, and J.J. Chrisman (Eds.) Family Business Studies: An Annotated Bibliography. Northampton, MA: Edward Elgar.

Ding, S., B. Qu, and Z. Zhuang. 2011. Accounting Properties of Chinese Family Firms. Journal of Accounting, Auditing \& Finance 26(4): 623-640.

Donnelley, R.G. 1964. The Family Business. Harvard Business Review 42: 93-105.

Dunn, B. 1996. Family enterprises in the UK: a special sector? Family Business Review 9(2): 139-155.

Duran, P., N.Kammerlander, M. van Essen, and T. Zellweger. 2015. Doing more with less: Innovation input and output in family firms. Academy of Management Journal, in press.

Fan, J.P., T.J. Wong, and T. Zhang. 2007. Politically connected CEOs, corporate governance, and Post-IPO performance of China's newly partially privatized firms. Journal of Financial Economics 84(2): 330-357.

Firth, M., P.M. Fung, and O.M. Rui. 2006. Corporate performance and CEO compensation in China. Journal of Corporate Finance 12(4): 693-714.

Firth, M., P.M. Fung, and O.M. Rui. 2007. Ownership, two-tier board structure, and the informativeness of earnings-Evidence from China. Journal of Accounting and Public Policy 26(4): 463-496.

Frecka, T.J., and C.F. Lee. 1983. Generalized financial ratio adjustment processes and their implications. Journal of Accounting Research 21(1): 308-316.

Gedajlovic, E., M.H. Lubatkin, and W.S. Schulze. 2004. Crossing the threshold from founder management to professional management: A governance perspective. Journal of Management Studies 41(5): 899-912. 
Gómez-Mejía, L.R., C. Cruz, P. Berrone, and J. De Castro. 2011. The Bind that Ties: Socioemotional Wealth Preservation in Family Firms. Academy of Management Annals 5(1): 653-707.

Gómez-Mejía, L.R., K.T. Haynes, M. Núñez-Nickel, K.J.L. Jacobson, and J. MoyanoFuentes. 2007. Socioemotional wealth and business risks in family-controlled firms: Evidence from Spanish olive oil mills. Administrative Science Quarterly 52(1): 106137.

Gómez-Mejía, L.R., M. Makri, and M. Larraza-Kintana. 2010. Diversification decisions in family-controlled firms. Journal of Management Studies 47(2): 223-252.

Greve, H.R. 2003. A behavioral theory of R\&D expenditures and innovations: Evidence from shipbuilding. Academy of Management Journal 46(6): 685-702.

Grullon, G., G. Kanatas, and J.P. Weston. 2004. Advertising, breadth of ownership, and liquidity. Review of Financial Studies 17(2): 439-461.

Habbershon, T.G., M. Williams, and I.C. Macmillan. 2003. A unified systems perspective of family firm performance. Journal of Business Venturing 18(4): 451-465.

Haw, I., D. Qi, D. Wu, and W. Wu. 2005. Market Consequences of Earnings Management in Response to Security Regulations in China. Contemporary Accounting Research 22(1): 95-140.

Healy, P., Palepu, K., 2001. A review of the voluntary disclosure literature. Journal of Accounting and Economics 31, 405-440.

Holmes, K., B. Johnson, and M. Kirkpatrick. 1997. 1997 Index of Economic Freedom: Washington, D.C.: The Heritage Foundation, and New York, NY: Dow Jones \& Company, Inc.

Holmes, R.M., P. Bromiley, C.E. Devers, T.R. Holcomb, and J.B. McGuire. 2011. Management theory applications of prospect theory: Accomplishments, challenges, and opportunities. Journal of Management 37(4): 1069-1107.

Hovakimian, A., and G. Li. 2011. In search of conclusive evidence: How to test for adjustment to target capital structure. Journal of Corporate Finance 17(1): 33-44.

Hovakimian, A., and G. Li. 2012. Is the Partial Adjustment Model a Useful Tool for Capital Structure Research? Review of Finance 16: 733-754.

Hu, N., X. Li, L. Liu, B. Qi, and G. Tian. 2012. Can government policies induce earnings management behavior? Evidence from Chinese public listed firms. Journal of International Financial Management \& Accounting 23(3): 188-207.

Huyghebaert, N, and Wang, L. 2012. Expropriation of Minority Investors in Chinese Listed Firms: The Role of Internal and External Corporate Governance Mechanisms. Corporate Governance: An International Review, 20(3): 308-332.

Jensen, M.C., W.H. Meckling. 1976. Theory of the firm: Managerial behavior, agency costs and ownership structure. Journal of Financial Economics 3(4): 305-360.

Joseph, J., W. Ocasio, and M.H. McDonnell. 2014. The structural elaboration of board independence: Executive power, institutional logics, and the adoption of CEO-only 
board structures in U.S. corporate governance. Academy of Management Journal, 57: 1834-1858.

Kato, T., and C. Long. 2006. Executive compensation, firm performance, and corporate governance in China: Evidence from firms listed in the Shanghai and Shenzhen Stock Exchanges. Economic Development and Cultural Change 54(4): 945-983.

Kim, H., H. Kim, and P.M. Lee. 2008. Ownership structure and the relationship between financial slack and R\&D investments: Evidence from Korean firms. Organization Science 19(3): 404-418.

Kor, Y.Y. 2006. Direct and interaction effects of top management team and board compositions on R\&D investment strategy. Strategic Management Journal 27(11): 1081-1099.

Kotlar, J., and A. De Massis. 2013. Goal Setting in Family Firms: Goal Diversity, Social Interactions, and Collective Commitment to Family-Centered Goals. Entrepreneurship Theory \& Practice 37(6): 1263-1288.

Kotlar, J., A. De Massis, H. Fang, and F. Frattini. 2014a. Strategic Reference Points in Family Firms. Small Business Economics 43(3): 597-619.

Kotlar, J., A. De Massis, F. Frattini, M. Bianchi, and H. Fang. 2013. Technology Acquisition in Family and Non-Family Firms: A Longitudinal Analysis of Spanish Manufacturing Firms. Journal of Product Innovation Management 30(6): 1073-1088.

Kotlar, J., H. Fang, A. De Massis, and F. Frattini. 2014b. Profitability goals, control goals, and the R\&D investment decisions of family and nonfamily firms. Journal of Product Innovation Management 31(6): 1128-1145.

Krug, B., and H. Hendrischke. 2008. Framing China: Transformation and Institutional Change through Co-evolution. Management and Organization Review 4(1): 81-108.

La Porta, R., F. Lopez-de-Silanes, C. Pop-Eleches, and A. Shleifer. 2004. Judicial checks and balances. Journal of Political Economy 112(2): 445-470.

La Porta, R., F. Lopez-de-Silanes, and A. Shleifer. 1999. Corporate ownership around the world. Journal of Finance 54: 471-517.

La Porta, R., F. Lopez-de-Silanes, A. Shleifer, and R. Vishny. 2000a. Investor protection and corporate governance. Journal of Financial Economics 58: 3-27.

La Porta, R., F. Lopez-de-Silanes, A. Shleifer, and R. Vishny. 2000b. Agency problems and dividend policies around the world. Journal of Finance 55: 1-33.

Lin, N. 2011. Capitalism in China: A centrally managed capitalism (CMC) and its future. Management and Organization Review 7(1): 63-96.

Liu, Q., and Z.J. Lu. 2007. Corporate governance and earnings management in the Chinese listed companies: A tunneling perspective. Journal of Corporate Finance 13(5): 881906.

Liu, Q., and G. Xiao. 2004. Look who’s disguising profits. HKU mimeo. 
Lo, A., R. Wong, and M. Firth. 2010. Tax, financial reporting, and tunneling incentives for income shifting: An empirical analysis of the transfer pricing behavior of Chineselisted companies. Journal of the American Taxation Association 32 (2): 1-26.

Luo, J.H., D.F. Wan, D. Cai, and H. Liu. 2013. Multiple-Large-Shareholder Structure and Governance: The Role of Shareholder Numbers, Contest for Control, and Formal Institutions in Chinese Family Firms. Management and Organization Review 9(2): 265-294.

McConnell, J.J., and H. Servaes. 1990. Additional evidence on equity ownership and corporate value. Journal of Financial Economics 27(2): 595-612.

Miller, C.C., and L.B. Cardinal. 1994. Strategic planning and firm performance: A synthesis of more than two decades of research. Academy of Management Journal 37(6): 16491665.

Miller, K.D., and P. Bromiley. 1990. Strategic risk and corporate performance: An analysis of alternative risk measures. Academy of Management Journal 33(4): 756-779.

Morck, R., A. Shleifer, and R. Vishny. 1988. Management ownership and market valuation: An empirical analysis. Journal of Financial Economics 20: 293-315.

Morck, R., A. Shleifer, and R. Vishny. 1989. Alternative mechanisms of corporate control. American Economic Review 79: 842-852.

Munari, F., R. Oriani, and M. Sobrero. 2010. The effects of owner identity and external governance systems on R\&D investments: A study of Western European firms. Research Policy 39(8): 1093-1104.

Narayanan, M.P. 1985. Managerial incentives for short-run results. Journal of Finance 40: 1469-1484.

Nee, V. 1992. Organizational dynamics of market transition: Hybrid forms, property rights, and mixed economy in China. Administrative Science Quarterly 37(1): 1-27.

Peng, M.W., and Y. Luo. 2000. Managerial ties and firm performance in a transition economy: the nature of a micro-macro link. Academy of Management Journal 43(3): 486-501.

Pollak, R.A. 1985. A transaction cost approach to families and households. Journal of Economic Literature 23(2): 581-608.

Schulze, W.S., M.H. Lubatkin, and R.N. Dino. 2003a. Exploring the agency consequences of ownership dispersion among the directors of private family firms. Academy of Management Journal, 46(2): 179-194.

Schulze, W.S., M.H. Lubatkin, and R.N. Dino. 2003b. Toward a theory of agency and altruism in family firms. Journal of Business Venturing 18(4): 473-490.

Schulze, W.S., M.H. Lubatkin, R.N. Dino, and A.K. Buchholtz. 2001. Agency relationships in family firms: Theory and evidence. Organization Science 12(2): 99-116.

Sciascia, S., M. Nordqvist, P. Mazzola, and A. De Massis. 2015. Family Ownership and R\&D Intensity in Small and Medium-Sized Firms. Journal of Product Innovation Management 32(3): 349-360. 
Shefrin, H., M. Statman. 1984. Explaining investor preference for cash dividends. Journal of Financial Economics 13: 253-282.

Shleifer, A., and R.W. Vishny. 1989. Management entrenchment: The case of managerspecific investments. Journal of Financial Economics 25: 123-139.

Shleifer, A., and R.W. Vishny. 1997. A survey of corporate governance. Journal of Finance 52: 737-783.

Singh, J.V. 1986. Performance, slack, and risk taking in organizational decision making. Academy of Management Journal 29(3): 562-585.

Stein, J.C. 1989. Efficient capital markets, inefficient firms: A model of myopic corporate behavior. Quarterly Journal of Economics 104: 655-669.

Tagiuri, R., and J.A. Davis. 1992. On the goals of successful family companies. Family Business Review 5(1): 43-62.

Tihanyi, L., S. Graffin, and G. George. 2014. Rethinking governance in management research. Academy of Management Journal, 57(6): 1535-1543.

Tsang, E.W.K. 2002. Learning from overseas venturing experience: The case of Chinese family businesses. Journal of Business Venturing 17(1): 21-40.

Villalonga, B., and R. Amit. 2006. How do family ownership, control, and management affect firm value? Journal of Financial Economics 80: 385-417.

Walder, A.G. 2009. From control to ownership: China's managerial revolution. Management and Organization Review 7(1): 19-38.

Wang, H., and C. Qian. 2011. Corporate philanthropy and corporate financial performance: The roles of stakeholder response and political access. Academy of Management Journal 54(6): 1159-1181.

Wang, Y., S. Chen, B. Lin, and L. Wu. 2008. The frequency and magnitude of earnings management in China. Applied Economics 40: 3213-3225.

Wei, Z., F. Xie, and S. Zhang. 2005. Ownership structure and firm value in China's privatized firms: 1991-2001. Journal of Financial and Quantitative Analysis 40(1): 87-108.

Wiseman, R.M., and L.R. Gomez-Mejia. 1998. A behavioral agency model of managerial risk taking. Academy of Management Review. 23(1): 133-153.

Xin, K.K., and J.L. Pearce. 1996. Guanxi: Connections as substitutes for formal institutional support. Academy of Management Journal 39(6): 1641-1658.

Zellweger, T.M., F.W. Kellermanns, J.J. Chrisman, and J.H. Chua. 2012. Family control and family firm valuation by family CEOs: The importance of intentions for transgenerational control. Organization Science 23(3): 851-868. 
Table 1. Descriptive Statistics

\section{Panel A Sample Description and Comparison between Family and Non-family Firms}

\begin{tabular}{|c|c|c|c|c|c|c|c|c|c|}
\hline & \multicolumn{4}{|c|}{$\begin{array}{c}\text { Full Sample } \\
(\mathrm{N}=402)\end{array}$} & \multicolumn{2}{|c|}{$\begin{array}{c}\text { Family Firms } \\
(\mathrm{N}=246)\end{array}$} & \multicolumn{2}{|c|}{$\begin{array}{c}\text { Non-Family Firms } \\
(\mathrm{N}=156)\end{array}$} & \multirow{2}{*}{ Compare-Mean $t$-test } \\
\hline & Mean & S.D. & Min & Max & Mean & S.D. & Mean & S.D. & \\
\hline RDI & 0.024 & 0.049 & 0.000 & 0.750 & 0.029 & 0.059 & 0.016 & 0.026 & $2.607 * * *$ \\
\hline Family Involvement & 0.612 & 0.488 & 0 & 1 & 1.000 & -- & 0.000 & -- & -- \\
\hline $\mathrm{ROA}_{\mathrm{t}-1}$ & 0.004 & 1.031 & -20.548 & 0.390 & 0.065 & 0.071 & -0.092 & 1.650 & $1.495^{*}$ \\
\hline Firm Size $_{\mathrm{t}-1}$ & 20.867 & 1.191 & 14.403 & 24.327 & 20.942 & 1.067 & 20.749 & 1.359 & $1.587 *$ \\
\hline Firm Age & 11.557 & 3.917 & 4 & 22 & 10.785 & 3.732 & 12.776 & 3.903 & $-5.121 * * *$ \\
\hline Tobin's $\mathrm{Q}_{\mathrm{t}-1}$ & 2.274 & 2.072 & 0.722 & 33.083 & 2.448 & 2.440 & 2.001 & 1.254 & $2.117^{* *}$ \\
\hline Altman's Z-Score & 0.009 & 0.058 & -1.134 & 0.066 & 0.013 & 0.011 & 0.004 & 0.093 & $1.384 *$ \\
\hline Absorbed Slack $\mathrm{t}_{-1}$ & 1.392 & 5.106 & 0.474 & 102.903 & 1.147 & 0.696 & 1.779 & 8.152 & -1.211 \\
\hline Unabsorbed Slack $\mathrm{t}_{\mathrm{t}-1}$ & 1.858 & 1.259 & 0.002 & 9.042 & 1.823 & 1.194 & 1.912 & 1.357 & -0.685 \\
\hline Potential Slack $\mathrm{t}_{\mathrm{t}-1}$ & 1.377 & 8.408 & -5.973 & 166.252 & 1.025 & 1.890 & 1.932 & 13.295 & -1.054 \\
\hline
\end{tabular}

RDI is measured by the ratio of R\&D expenses and total sales. Family Involvement is a dummy variable based on family ownership and family involvement in management. ROA is return on assets, Firm Size is measured by the natural logarithm of total sales, and Firm Age is based on the year in which a firm was founded. Tobin's Q is measured by the market-to-book ratio, and Altman's z-score captures firm characteristics (2) and current liabilities. Potential Slack captures the nature of a firm's financing structure using its debt-to-equity ratio. *, **, and *** denote significance at the $10 \%, 5 \%$, and $1 \%$ level respectively. 


\section{Panel B Comparison between Sample Firms and Firms with Missing Values for R\&D Expenses}

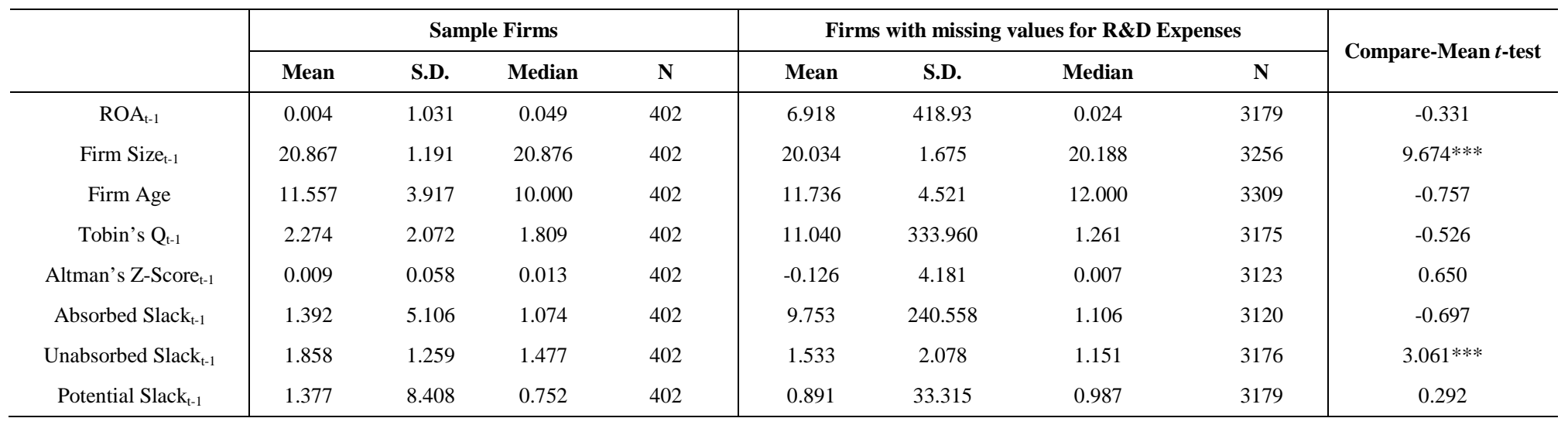

ROA is return on assets, Firm Size is measured by the natural logarithm of total sales, and Firm Age is based on the year in which a firm was founded. Tobin’s Q is measured by the market-to-book ratio, and Altman's z-score captures firm characteristics on potential bankruptcy. Absorbed Slack estimates the proportion of total sales spent on selling, general and administrative expenses. Unabsorbed Slack characterizes the liquidity using the ratio between current assets and current liabilities. Potential Slack captures the nature of a firm's financing structure using its debt-to-equity ratio. *, **, and $* * *$ denote significance at the $10 \%, 5 \%$, and $1 \%$ level respectively. 
Table 2. Main Results from Equation (1)-(5) (N=402)

\begin{tabular}{|c|c|c|c|c|c|c|c|c|c|c|}
\hline & \multicolumn{2}{|c|}{ (1) } & \multicolumn{2}{|c|}{$(2)$} & \multicolumn{2}{|c|}{ (3) } & \multicolumn{2}{|c|}{ (4) } & \multicolumn{2}{|c|}{ (5) } \\
\hline & Coef. & $t$ & Coef. & $t$ & Coef. & $t$ & Coef. & $t$ & Coef. & $t$ \\
\hline Family Involvement & & & $0.011^{* *}$ & 2.17 & & & $0.011^{* *}$ & 2.06 & $0.016^{* * *}$ & 2.75 \\
\hline Performance Above Historical Aspiration Level & & & & & -0.006 & -0.35 & -0.004 & -0.23 & -0.001 & -0.04 \\
\hline Performance Below Historical Aspiration Level & & & & & 0.016 & 0.71 & 0.009 & 0.41 & 0.038 & 0.81 \\
\hline Performance Above Industry Aspiration Level & & & & & -0.000 & -0.63 & -0.000 & -0.59 & -0.000 & -0.51 \\
\hline Performance Below Industry Aspiration Level & & & & & 0.000 & 0.44 & 0.000 & 0.53 & 0.000 & 1.20 \\
\hline $\begin{array}{c}\text { Family Involvement } \times \text { Performance Above } \\
\text { Historical Aspiration Level }\end{array}$ & & & & & & & & & $-0.174^{* *}$ & -2.48 \\
\hline Family Involvement $\times$ Performance Below Historical Aspiration Level & & & & & & & & & -0.049 & -0.90 \\
\hline $\begin{array}{c}\text { Family Involvement } \times \text { Performance Above } \\
\text { Industry Aspiration Level }\end{array}$ & & & & & & & & & 0.000 & 0.09 \\
\hline $\begin{array}{c}\text { Family Involvement } \times \text { Performance Below } \\
\text { Industry Aspiration Level }\end{array}$ & & & & & & & & & -0.000 & -1.14 \\
\hline $\mathrm{ROA}_{\mathrm{t}-1}$ & 0.031 & 0.94 & 0.028 & 0.84 & 0.046 & 1.19 & 0.037 & 0.94 & $0.155^{* *}$ & 2.48 \\
\hline Firm Size $\mathrm{t}_{\mathrm{t}-1}$ & 0.000 & 0.17 & 0.000 & 0.08 & 0.001 & 0.23 & 0.000 & 0.12 & -0.001 & -0.21 \\
\hline Firm Age & -0.001 & -1.04 & -0.000 & -0.39 & -0.001 & -1.08 & -0.000 & -0.43 & -0.000 & -0.14 \\
\hline Tobin's $\mathrm{Q}_{\mathrm{t}-1}$ & -0.000 & -0.05 & -0.000 & -0.11 & 0.000 & 0.00 & -0.000 & -0.07 & 0.000 & 0.16 \\
\hline Altman's Z-Score ${ }_{t-1}$ & 0.170 & 0.46 & 0.156 & 0.42 & 0.060 & 0.14 & 0.090 & 0.21 & -0.184 & -0.41 \\
\hline Absorbed Slack $k_{t-1}$ & 0.008 & 1.16 & 0.007 & 1.05 & 0.007 & 0.94 & 0.007 & 0.91 & $0.022 * *$ & 2.07 \\
\hline Unabsorbed Slack $\mathrm{k}_{\mathrm{t}-1}$ & $0.005^{* *}$ & 0.023 & $0.006^{* *}$ & 2.54 & $0.005^{* *}$ & 2.19 & $0.006^{* *}$ & 2.46 & $0.005^{*}$ & 1.95 \\
\hline Potential Slack $\mathrm{t}_{-1}$ & -0.000 & -0.30 & -0.000 & -0.20 & -0.000 & 0.36 & -0.000 & -0.25 & 0.000 & -0.41 \\
\hline Year Dummies & \multicolumn{2}{|c|}{ Yes } & \multicolumn{2}{|c|}{ Yes } & \multicolumn{2}{|c|}{ Yes } & \multicolumn{2}{|c|}{ Yes } & \multicolumn{2}{|c|}{ Yes } \\
\hline Industry Dummies & \multicolumn{2}{|c|}{ Yes } & \multicolumn{2}{|c|}{ Yes } & \multicolumn{2}{|c|}{ Yes } & \multicolumn{2}{|c|}{ Yes } & \multicolumn{2}{|c|}{ Yes } \\
\hline Constant & 0.001 & 0.02 & 0.003 & 0.05 & 0.002 & 0.03 & 0.003 & 0.06 & 0.002 & 0.04 \\
\hline F-Value & \multicolumn{2}{|c|}{$3.10^{* * *}$} & \multicolumn{2}{|c|}{$3.20^{* * *}$} & \multicolumn{2}{|c|}{$2.65^{* * *}$} & \multicolumn{2}{|c|}{$2.74^{* * *}$} & \multicolumn{2}{|c|}{$2.69^{* * *}$} \\
\hline Adjusted $\mathrm{R}^{2}$ & \multicolumn{2}{|c|}{0.1035} & \multicolumn{2}{|c|}{0.112} & \multicolumn{2}{|c|}{0.097} & \multicolumn{2}{|c|}{0.105} & \multicolumn{2}{|c|}{0.115} \\
\hline
\end{tabular}

RDI is measured by the ratio of R\&D expenses and total sales. Family Involvement is a dummy variable based on family ownership and family involvement in management. Performance Below Historical Aspiration Level, Performance Above Historical Aspiration Level, Performe Below Industry Aspiration Lel and Performance Above Industry Aspiration Level are four performance-aspiration-gap variables. ROA is return on assets, Firm Size is measured by the natural logarithm of total sales, and Firm Age is based on the year in which a firm was founded. Tobin's Q is measured by the market-to-book ratio, and Altman's z-score captures firm characteristics on potential bankruptcy. Absorbed Slack estimates the proportion of total sales spent on selling, general and administrative expenses. Unabsorbed Slack characterizes the liquidity using the ratio between current assets and current liabilities. Potential Slack captures the nature of a firm's financing structure using its debt-to-equity ratio. *, **, and ${ }^{* * *}$ denote significance at the $10 \%, 5 \%$, and $1 \%$ level respectively. 
Table 3. Robustness Tests (N=402)

\begin{tabular}{|c|c|c|c|c|c|c|c|c|c|c|c|c|}
\hline & \multicolumn{8}{|c|}{ OLS } & \multicolumn{2}{|c|}{ Stage 1 (Probit) } & \multicolumn{2}{|c|}{ Stage 2(OLS) } \\
\hline & \multirow{2}{*}{$\begin{array}{c}\text { Coef. } \\
0.013^{* *}\end{array}$} & $T$ & Coef. & $t$ & \multirow{2}{*}{$\begin{array}{ll}\text { Coef. } \\
0.015^{* * *}\end{array}$} & \multirow{2}{*}{\begin{tabular}{c|}
$t$ \\
2.67
\end{tabular}} & Coef. & $t$ & Coef. & $z$ & \multirow{2}{*}{$\begin{array}{ll}\text { Coef. } \\
0.015^{* * *}\end{array}$} & \multirow{2}{*}{$\frac{t}{2.58}$} \\
\hline Family Involvement & & 2.36 & $0.014^{* *}$ & 2.55 & & & \multirow[t]{2}{*}{$0.013^{* *}$} & \multirow[t]{2}{*}{2.32} & & & & \\
\hline Performance Above Historical Aspiration Level & & & 0.001 & 0.07 & -0.000 & -0.01 & & & & & -0.001 & -0.07 \\
\hline Performance Below Historical Aspiration Level & 0.042 & 0.89 & & & 0.042 & 0.90 & & & & & 0.051 & 0.58 \\
\hline Performance Above Industry Aspiration Level & & & -0.000 & -0.54 & & & -0.000 & -0.47 & & & -0.000 & -0.47 \\
\hline Performance Below Industry Aspiration Level & 0.000 & 1.30 & & & & & 0.000 & 1.34 & & & 0.000 & 1.14 \\
\hline $\begin{array}{l}\text { Family Involvement } \times \text { Performance Above } \\
\text { Historical Aspiration Level }\end{array}$ & & & $-0.177 * *$ & -2.55 & $-0.178^{* *}$ & -2.54 & & & & & $-0.169 * *$ & -2.29 \\
\hline Family Involvement $\times$ Performance Below Historical Aspiration Level & -0.042 & -0.79 & & & -0.052 & -0.97 & & & & & -0.601 & -0.66 \\
\hline $\begin{array}{l}\text { Family Involvement } \times \text { Performance Above } \\
\text { Industry Aspiration Level }\end{array}$ & & & 0.000 & 0.19 & & & 0.000 & 0.03 & & & 0.000 & 0.06 \\
\hline $\begin{array}{c}\text { Family Involvement } \times \text { Performance Below } \\
\text { Industry Aspiration Level }\end{array}$ & -0.000 & -1.20 & & & & & -0.000 & -1.31 & & & -0.000 & -1.08 \\
\hline $\mathrm{ROA}_{\mathrm{t}-1}$ & 0.064 & 1.28 & $0.122^{* *}$ & 2.44 & $0.158^{* *}$ & 2.53 & 0.030 & 0.90 & $2.975^{* *}$ & 2.24 & 0.106 & 0.87 \\
\hline Firm Size $_{t-1}$ & -0.000 & -0.08 & -0.000 & -0.06 & -0.001 & -0.22 & 0.000 & 0.07 & 0.104 & 1.43 & -0.002 & -0.45 \\
\hline Firm Age & -0.000 & -0.41 & -0.000 & -0.16 & -0.000 & -0.14 & -0.000 & -0.39 & $-0.100 * * *$ & -5.35 & 0.002 & 0.42 \\
\hline Tobin's $\mathrm{Q}_{\mathrm{t}-1}$ & -0.000 & -0.23 & 0.001 & 0.28 & 0.001 & 0.30 & -0.001 & -0.25 & 0.029 & 0.45 & 0.000 & 0.14 \\
\hline Altman's Z-Score ${ }_{t-1}$ & 0.030 & 0.08 & -0.053 & -0.12 & -0.193 & -0.43 & 0.156 & 0.42 & $-17.212^{*}$ & -1.74 & 0.090 & 0.12 \\
\hline Absorbed Slack $\mathrm{t}_{\mathrm{t}-1}$ & 0.005 & 0.63 & $0.024 * *$ & 2.50 & $0.021^{* *}$ & 2.05 & 0.008 & 1.12 & & & $0.021 *$ & 1.87 \\
\hline Unabsorbed Slack $\mathrm{t}_{\mathrm{t}-1}$ & $0.005^{* *}$ & 2.25 & $0.005^{* *}$ & 2.18 & $0.005 *$ & 1.92 & $0.006 * *$ & 2.53 & & & $0.005 *$ & 1.89 \\
\hline Potential Slack $\mathrm{t}_{\mathrm{t}-1}$ & -0.000 & -0.24 & -0.000 & -0.37 & -0.000 & -0.39 & -0.000 & -0.22 & & & -0.000 & -0.42 \\
\hline CRISIS & & & & & & & & & $0.534 * *$ & 2.34 & & \\
\hline IMR & & & & & & & & & & & -0.029 & -0.45 \\
\hline Year Dummies & $\mathrm{Ye}$ & & $\mathrm{Y}$ & & $\mathrm{Ye}$ & & & & $\mathrm{Ye}$ & & $\mathrm{Ye}$ & \\
\hline Industry Dummies & $\mathrm{Ye}$ & & & & $\mathrm{Ye}$ & & & & $\mathrm{Ye}$ & & $\mathrm{Ye}$ & \\
\hline Constant & 0.016 & 0.27 & -0.010 & -0.18 & 0.002 & 0.04 & 0.004 & 0.07 & -2.020 & -1.26 & 0.048 & 0.36 \\
\hline F-Value & 2.82 & & 3.00 & & 3.03 & & 2.8 & & 620 & & 2.84 & \\
\hline Adjusted $\mathrm{R}^{2}$ & 0.10 & & 0.1 & & 0.12 & & 0.1 & & & & 0.11 & \\
\hline Pseudo $\mathrm{R}^{2}$ & & & & & & & & & 0.11 & & & \\
\hline
\end{tabular}

RDI is measured by the ratio of R\&D expenses and total sales. Family Involvement is a dummy variable based on family ownership and family involvement in management. Performance Below Historical Aspiration Level, Performance Above Historical Aspiration Level, Performance Below Industry Aspiration Level, and Performance Above Industry Aspiration Level are four performance-aspiration-gap variables. ROA is return on assets, Firm Size is measured by the natural logarithm of total sales, and Firm Age is based on the year in which a firm was founded. Tobin's Q is measured by the market-to-book ratio, and Altman's z-score captures firm characteristics on potential bankruptcy. Absorbed Slack estimates the proportion of total sales spent on selling, general and administrative expenses. Unabsorbed Slack characterizes the liquidity using the ratio between current assets and current liabilities. Potential Slack captures the nature of a firm's financing structure using its debt-to-equity ratio. *, **, and $* * *$ denote significance at the $10 \%$, $5 \%$, and $1 \%$ level respectively. 
Table 4. Comparison between Evidence in Two Different Contexts

\begin{tabular}{|c|c|c|}
\hline & US Family Firms & $\begin{array}{c}\text { Chinese family } \\
\text { Firms }\end{array}$ \\
\hline Family Involvement & - & + \\
\hline Family Involvement $\times$ Performance Above Historical Aspiration Level & - & $-*$ \\
\hline Family Involvement $\times$ Performance Below Historical Aspiration Level & + & No Effect \\
\hline Family Involvement × Performance Above Industry Aspiration Level & - & No Effect \\
\hline Family Involvement × Performance Below Industry Aspiration Level & + & No Effect \\
\hline
\end{tabular}

* Although we show the same sign of the coefficient of the interactive term, the interpretation is different. U.S. family firms are driven by their pursuit of non-economic goals while Chinese family firms are found to use strategic mechanisms to deal with the distinct sociopolitical environment. 
Figure 1. Graphical Plots of Interaction Term: Family Involvement $\times$ Performance Above Historical Aspiration Level

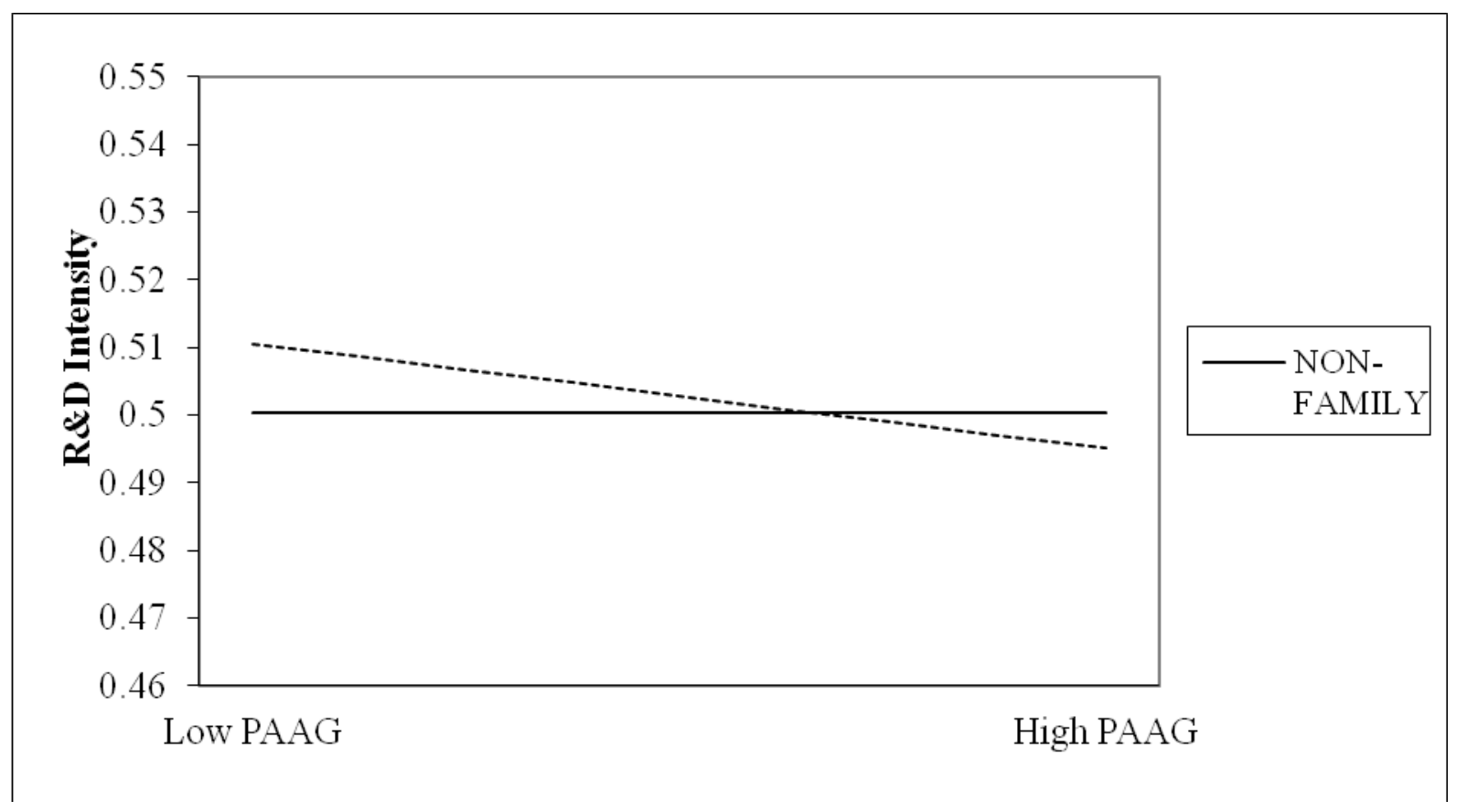

